\title{
Geology
}

\section{Earthquake-triggered increase in sediment delivery from an active mountain belt}

Simon J. Dadson, Niels Hovius, Hongey Chen, W. Brian Dade, Jiun-Chuan Lin, Mei-Ling Hsu, Ching-Weei Lin, Ming-Jame Horng, Tien-Chien Chen, John Milliman and Colin P. Stark

Geology 2004;32;733-736

doi: $10.1130 / \mathrm{G} 20639.1$

Email alerting services

Subscribe

Permission request click www.gsapubs.org/cgi/alerts to receive free e-mail alerts when new articles cite this article

click www.gsapubs.org/subscriptions/ to subscribe to Geology

click http://www.geosociety.org/pubs/copyrt.htm\#gsa to contact GSA

Copyright not claimed on content prepared wholly by U.S. government employees within scope of their employment. Individual scientists are hereby granted permission, without fees or further requests to GSA, to use a single figure, a single table, and/or a brief paragraph of text in subsequent works and to make unlimited copies of items in GSA's journals for noncommercial use in classrooms to further education and science. This file may not be posted to any Web site, but authors may post the abstracts only of their articles on their own or their organization's Web site providing the posting includes a reference to the article's full citation. GSA provides this and other forums for the presentation of diverse opinions and positions by scientists worldwide, regardless of their race, citizenship, gender, religion, or political viewpoint. Opinions presented in this publication do not reflect official positions of the Society.

\section{Notes}

Geological Society of America

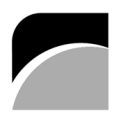

THE

GEOLOGICAL

SOCIETY

OF AMERICA 


\title{
Earthquake-triggered increase in sediment delivery from an active mountain belt
}

\author{
Simon J. Dadson \\ Niels Hovius \\ Hongey Chen Department of Geosciences, National Taiwan University, No. 1, Sec. 4, Roosevelt Road, Taipei, Taiwan, \\ Republic of China \\ W. Brian Dade Department of Earth Sciences, Dartmouth College, Hanover, New Hampshire 03755, USA \\ Jiun-Chuan Lin ] Department of Geography, National Taiwan University, No. 1, Sec. 4, Roosevelt Road, Taipei, Taiwan, \\ Mei-Ling Hsu $]$ Republic of China \\ Ching-Weei Lin Department of Earth Sciences, National Cheng Kung University, 1 Ta-Hsueh Road, Tainan, Taiwan, Republic \\ of China
}

Ming-Jame Horng Water Resources Agency, Ministry of Economic Affairs, Hsin-Yi Road, Taipei, Taiwan, Republic of China Tien-Chien Chen National Science and Technology Center for Disaster Prevention, 6F\#200, Sec. 3, Hsinhai Road, Taipei, Taiwan, Republic of China

John Milliman School of Marine Sciences, College of William and Mary, Gloucester Point, Virginia 23062, USA

Colin P. Stark Lamont-Doherty Earth Observatory of Columbia University, Palisades, New York 10964, USA

\section{ABSTRACT}

In tectonically active mountain belts, earthquake-triggered landslides deliver large amounts of sediment to rivers. We quantify the geomorphic impact of the $1999 \mathrm{M}_{\mathrm{w}}$ 7.6 Chi-Chi earthquake in Taiwan, which triggered $>\mathbf{2 0 , 0 0 0}$ landslides. Coseismic weakening of substrate material caused increased landsliding during subsequent typhoons. Most coseismic landslides remained confined to hillslopes. Downslope transport of sediment into the channel network occurred during later storms. The sequential processes have led to a factor-of-four increase in unit sediment concentration in rivers draining the epicentral area and increased the magnitude and frequency of hyperpycnal sediment delivery to the ocean. Four years after the earthquake, rates of hillslope mass wasting remain elevated in the epicentral area.

Keywords: earthquakes, landslides, typhoons, sediment supply, fluvial erosion rates, Taiwan.

\section{INTRODUCTION}

Earthquake- and storm-triggered landslides in actively deforming orogens increase the supply of sediment to rivers (Lyell, 1830; Keefer, 1994; Eberhart-Phillips et al., 2003). The decadal pattern of sediment yield from seismically active areas such as Taiwan is controlled by large earthquakes (Dadson et al., 2003). Coseismic landslide intensity is known to correlate with earthquake magnitude (Keefer, 1994), but patterns of landslide intensity around active faults and location with respect to the river network are poorly constrained. These patterns control the distribution of coseismic erosion and sediment delivery to rivers. After an earthquake, coseismic landslide debris is flushed from catchments (Pain and Bowler, 1973; Pearce and Watson, 1986), and seismically weakened rock mass may be removed from hillslopes, but these processes have not been documented in detail. We have quantified the hillslope and fluvial responses to the $\mathrm{M}_{\mathrm{w}}$ 7.6 Chi-Chi earthquake in Taiwan by using data on ground acceleration, topography, landsliding, and fluvial sediment transport.

Taiwan is the product of oblique collision between the Luzon arc, on the Philippine Sea plate, and the Eurasian continental margin (Fig. 1A). Crustal shortening at $80 \mathrm{~mm} \cdot \mathrm{yr}^{-1}$ (Yu et al., 1997) is accompanied by frequent large earthquakes, including the $\mathrm{M}_{\mathrm{w}}$ 7.6 Chi-Chi earthquake in 1999. Taiwan has a subtropical climate with an average of four typhoons per year (Wu and Kuo, 1999) and mean precipitation of $2.5 \mathrm{~m} \cdot \mathrm{yr}^{-1}$. This combination of active tectonic and climatic regimes leads to erosion rates averaging $3-7 \mathrm{~mm} \cdot \mathrm{yr}^{-1}$ and locally up to 60 $\mathrm{mm} \cdot \mathrm{yr}^{-1}$ (Dadson et al., 2003), driven by fluvial bedrock incision (Hartshorn et al., 2002), landsliding (Hovius et al., 2000), and debris flows (Lin et al., 2004). Average suspended-sediment discharge from Taiwan to the ocean between 1970 and 1998 was $\sim 400 \mathrm{Mt} \cdot \mathrm{yr}^{-1}$ (Dadson et al., 2003).

The $M_{w}$ 7.6 Chi-Chi earthquake, on 21 September 1999, was the largest in Taiwan for $50 \mathrm{yr}$ and the largest on the Chelungpu thrust fault in 300-620 yr (Shin and Teng, 2001; Chen et al., 2001). The earthquake had a reverse fault mechanism, a focal depth of $8 \mathrm{~km}$, and resulted from the rupture of an $\sim 100 \mathrm{~km}$ segment of the north-trending, east-dipping $\left(\sim 30^{\circ}\right)$ Chelungpu thrust. It produced ground accelerations of up to $1 g$ (Lin et al., 2000). Geodetic observations show coseismic displacement of as much as $3 \mathrm{~m}$ on the fault, decreasing to zero at a distance of $20 \mathrm{~km}$ away from the fault (Yu et al., 2001).

Here we focus on the Choshui River basin, which drains much of the epicentral area. During 1996-2001, the following events occurred (Central Weather Bureau, 2003): (1) Typhoon Herb (August 1996), (2) Chi-Chi earthquake (September 1999), and (3) Typhoon Toraji (July 2001). Typhoon Herb occurred $80 \mathrm{yr}$ after the previous $M_{w}>6$ earthquake in the area and produced a total water discharge of $1.2 \mathrm{~km}^{3}$ over 3 days from the Choshui River (Fig. 1B). Similarly, Typhoon Toraji

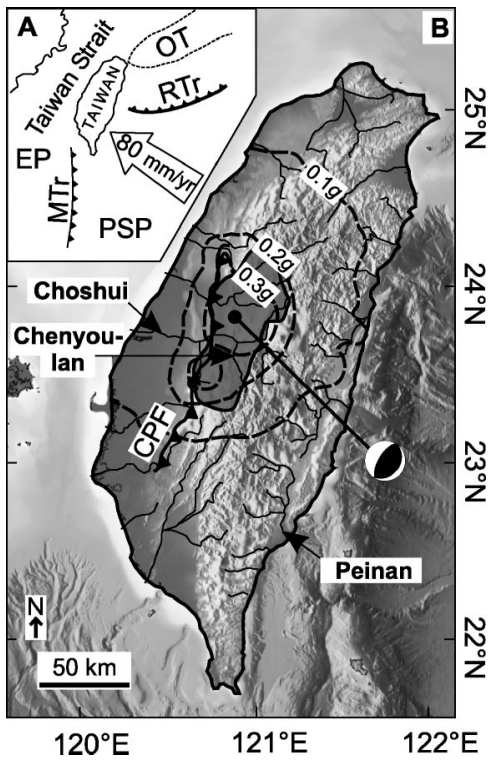

Figure 1. Location and tectonics of Taiwan. A: Tectonic features of Taiwan area. Abbreviations: EP-Eurasian plate; PSP-Philippine Sea plate; MTr-Manila Trench; RTr-Ryukyu Trench; OTOkinawa Trough (Teng, 1990). B: Topography of Taiwan, showing epicenter and focal mechanism of Chi-Chi earthquake. Dashed lines are peak vertical ground acceleration contours constructed using data from 441 strong motion recorders, 60 of which were within $20 \mathrm{~km}$ of Chelungpu fault (CPF) (Lee et al., 2001). Shaded region with solid outline indicates area of widespread landsliding (>2\% surface area disturbed) measured from aerial-photograph landslide inventory. 


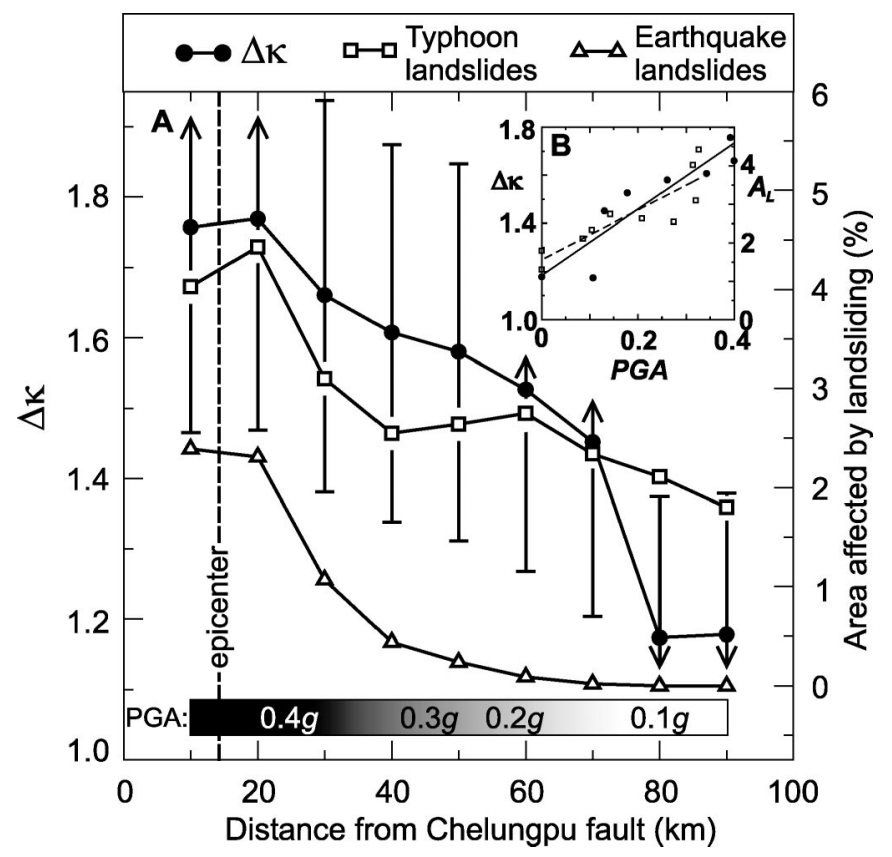

Figure 2. A: Geomorphic response to earthquake with distance from Chelungpu fault. Filled circles show mean change in unit sediment concentration, $\Delta \kappa$ (1 standard error bars); open symbols show mean change in density of landsliding caused by ChiChi earthquake (triangles) and Typhoon Toraji (squares). Gray bar shows peak (vertical) ground acceleration (PGA). B: Relationship between PGA, area affected by landsliding (dashed line), and $\Delta \kappa$ (solid line).

(the largest of four postearthquake typhoons) produced a total water discharge from the Choshui River of $0.8 \mathrm{~km}^{3}$ over 2 days. This typhoon-earthquake-typhoon sequence represents a natural experiment that provides quantitative information about the impact of a large earthquake on hillslope mass wasting and transfer of sediment to rivers and the ocean.

\section{LANDSLIDE LOCATION AND INTENSITY}

Field, aerial-photograph, and satellite observations following the Chi-Chi earthquake show $\sim 20,000$ soil and bedrock landslides, covering a total area of $150 \mathrm{~km}^{2}$. Landslides were mapped from 20-mresolution SPOT satellite images. This resolution means that landslides $>3600 \mathrm{~m}^{2}(3 \times 3$ pixels $)$ can be mapped accurately. Omission of landslides smaller than this size may have caused significant underestimation of area disturbed. Most slope failures occurred within an $\sim 3000 \mathrm{~km}^{2}$ region bounded by the $0.2 \mathrm{~g}$ contour of peak vertical ground acceleration (Lin et al., 2000; Fig. 1B). The area disturbed by landsliding exceeds $2 \%$ within an $\sim 20 \mathrm{~km}$ zone along the Chelungpu fault (Fig. 2A). This zone includes the earthquake epicenter, $14 \mathrm{~km}$ east of the surface break. The decrease in area affected by landsliding away from the epicenter is characterized by an exponential function that decays to $1 / e(37 \%)$ of its maximum value within $30 \mathrm{~km}$ (Fig. 2A).

After Typhoon Toraji, 30,000 more landslides were mapped from SPOT images, with a total mapped landslide area of $500 \mathrm{~km}^{2}$. Of the landslides triggered by the Chi-Chi earthquake, $56 \%$ were reactivated during Typhoon Toraji, while $80 \%$ of the Toraji landslides occurred in areas that had not failed during the earthquake. Moreover, the proportion of surface area disturbed by landsliding during Typhoon Toraji increased with proximity to the Chelungpu fault (Fig. 2A), suggesting that, even in areas that underwent no landsliding during the earthquake, the substrate was preconditioned to fail through loss of cohesion and frictional strength of hillslope rock mass caused by seismic strong ground motion.

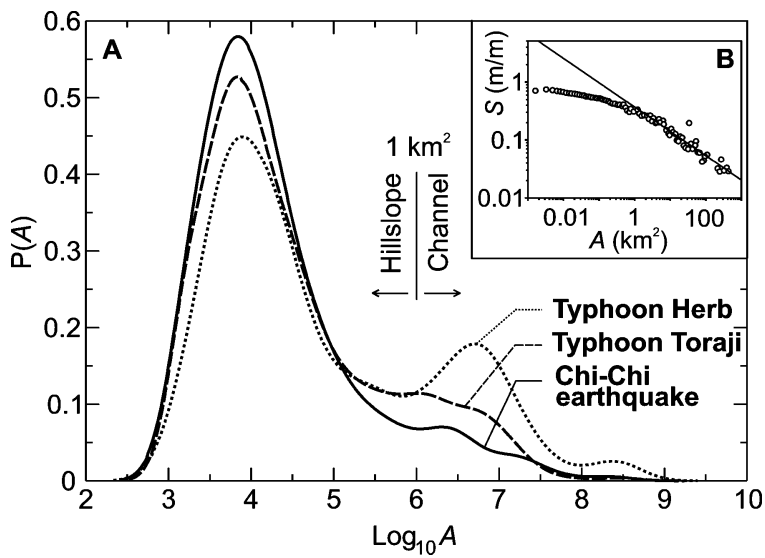

Figure 3. A: Probability $(P)$ distribution of upslope area $\left(A\right.$, in $\left.\mathrm{m}^{2}\right)$ of lowermost point reached by landslides triggered by Typhoon Herb (dotted line), Typhoon Toraji (dashed line), and Chi-Chi earthquake (solid line). $A$ was calculated using ARC/INFO D8 flow routing algorithm with $40 \mathrm{~m}$ digital elevation model. Value reported is maximum found within perimeter of each landslide scar and its associated deposit. B: Slope (S) vs. area plot for Chenyoulan River. Slope is mean slope measured in direction of steepest descent within logarithmically spaced bins of drainage area. Solid line is power law $(S=$ $0.36 A^{-0.42}$ ) that was fitted to data with $A>1 \mathrm{~km}^{2}$.

Next we consider the location of landslides within the Chenyoulan River basin, a tributary of the Choshui River; the basin covers an area of $376 \mathrm{~km}^{2}, \sim 12 \mathrm{~km}$ east of the epicenter (Fig. 1B). Within the Chenyoulan catchment, 289 landslides were mapped following Typhoon Herb, 584 following the Chi-Chi earthquake, and 1903 following Typhoon Toraji. To quantify landslide location relative to the riverchannel network, we calculated the drainage area, $A$, of the lowest point reached by each landslide (Fig. 3A). A slope-area plot (Fig. 3B) produced from a $40 \mathrm{~m}$ digital elevation model of the Chenyoulan catchment indicates that channelization occurs when $A>1 \mathrm{~km}^{2}$. We infer that landslides reaching locations with $A>1 \mathrm{~km}^{2}$ delivered sediment to channels.

Most earthquake-triggered landslides remained confined to hillslopes. Only $8 \%$ of these landslides delivered sediment to rivers. In contrast, $13 \%$ of landslides triggered by Typhoon Toraji, and $24 \%$ of landslides triggered by Typhoon Herb, delivered sediment to the channel network (Fig. 2B). This difference may reflect topographic amplification of seismic waves close to hillcrests (Geli et al., 1988). Subsequent downslope transport occurred in a cascade of sediment from hillslopes into the channel network during storm-triggered landslides and debris flows.

\section{SUSPENDED SEDIMENT IN RIVERS}

We have quantified the impact of the Chi-Chi earthquake and Typhoon Toraji on river sediment loads by using measurements of suspended-sediment discharge at 101 hydrometric stations between 21 September 1999 and the end of 2001. Water discharge was measured daily through the use of a stage recorder. Suspended-sediment concentration was measured fortnightly, through the use of a USDH-48 suspended-sediment sampler, by the Water Resources Agency of Taiwan (1970-2003). To estimate coseismic sediment supply independently of variations in transport capacity during subsequent storms, we calculated unit sediment concentration, $\kappa$, from a plot of suspendedsediment concentration and water discharge (Trustrum et al., 1999; e.g., Figs. 4A, 4B) by fitting a function of the form $C=\kappa Q^{\mathrm{b}}$, where $C$ is suspended-sediment concentration $(\mathrm{g} / \mathrm{L})$ and $Q$ is water discharge $\left(\mathrm{m}^{3} \cdot \mathrm{s}^{-1}\right)$. The exponent $b$ represents the strength of the relationship between $Q$ and $C$ and is determined by the process of sediment mo- 

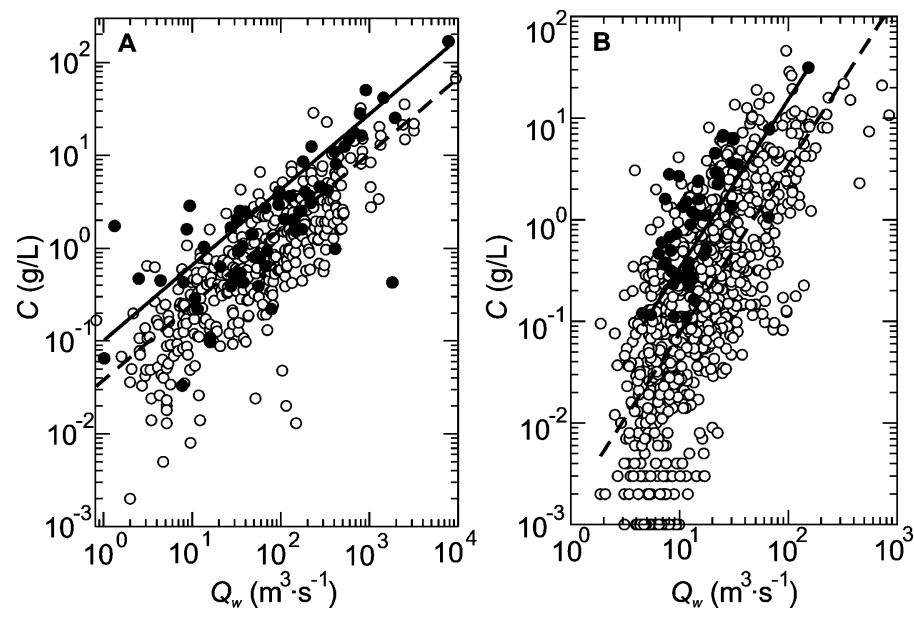

Figure 4. Suspended-sediment rating curves. A: Choshui River. B: Chenyoulan River. Open circles show measurements made before Chi-Chi earthquake; filled symbols show measurements after earthquake. Dashed lines are power-law functions of $C=\kappa_{\text {pre }} Q^{b}$ fitted to preearthquake data using log-transformed least-squares regression solid lines are power-law functions $C=\kappa_{\text {post }} Q^{b}$ fitted only to postearthquake data; $b$ was 0.8 for Choshui River, and 1.7 for Chenyoulan River. See text for discussion.

bilization. By fitting model curves to both preearthquake and postearthquake data, while keeping the exponent fixed to permit comparison between models, we obtained model coefficients $\kappa_{\text {pre }}$ and $\kappa_{\text {post }}$. The ratio $\Delta \kappa=\kappa_{\text {post }} / \kappa_{\text {pre }}$ gives an estimate of the change in unit sediment concentration following the earthquake. If $\Delta \kappa>1$, unit sediment concentration increased after the earthquake. ${ }^{1}$

The spatial pattern of $\Delta \kappa$ shows the greatest perturbation in the Chi-Chi epicentral region, in a north-trending band that tracks the Chelungpu fault. The change in unit sediment concentration tracks the patterns of peak vertical ground acceleration and landslide density (Fig. $5 \mathrm{~A})$. Beyond the epicentral peak, $\Delta \kappa$ decreases gently in the first 60 $\mathrm{km}$ from the fault and then decays more rapidly (Fig. 2A). This pattern is broadly similar to the pattern of landslide disturbance, although landslide density decays more rapidly away from the fault. Peak vertical ground acceleration correlates well with area disturbed by landsliding $\left(r^{2}=0.76\right)$ and with change in unit sediment concentration $\left(r^{2}=0.86\right)$ (Fig. 2B). In the Peinan River, which is a considerable distance from the Chi-Chi epicenter (Fig. 1B), unit sediment concentration increased by a factor of 2.8. Here, elevated sediment concentrations and discharges appear to have resulted from sediment mobilized by debris flows during Typhoon Bilis, which impinged directly on this highyielding mountain watershed. The track of Typhoon Toraji is offset from a zone of increased sediment concentration that it may have caused. Possible explanations for the mismatch include variability of the precipitation field associated with typhoons or the interaction of typhoons with topography.

Sediment discharge to the ocean was elevated following the ChiChi earthquake and Typhoon Toraji. The area most heavily affected by the earthquake was around the epicentral Choshui River (Fig. 1B). Following the earthquake, unit sediment concentration at the Choshui River mouth increased by a factor of 3.8 (Fig. 4A). The maximum suspended-sediment concentration measured during Typhoon Toraji $\left(169 \mathrm{~g} / \mathrm{L}\right.$; measured at water discharge, $Q=8900 \mathrm{~m}^{3} \cdot \mathrm{s}^{-1} ; Q_{\text {peak }}=$ $\left.28,000 \mathrm{~m}^{3} \cdot \mathrm{s}^{-1}\right)$ was 2.5 times greater than during Typhoon Herb (67 $\mathrm{g} / \mathrm{L}$; measured at $\left.Q=5850 \mathrm{~m}^{3} \cdot \mathrm{s}^{-1} ; Q_{\text {peak }}=14,800 \mathrm{~m}^{3} \cdot \mathrm{s}^{-1}\right)$, which was of similar size but occurred $3 \mathrm{yr}$ before the Chi-Chi earthquake.

${ }^{1}$ GSA Data Repository item 2004119, Table of $\Delta \kappa$ calculations for major watersheds, is available online at www.geosociety.org/pubs/ft2004.htm, or on request from editing@geosociety.org or Documents Secretary, GSA, P.O. Box 9140, Boulder, CO 80301-9140, USA.

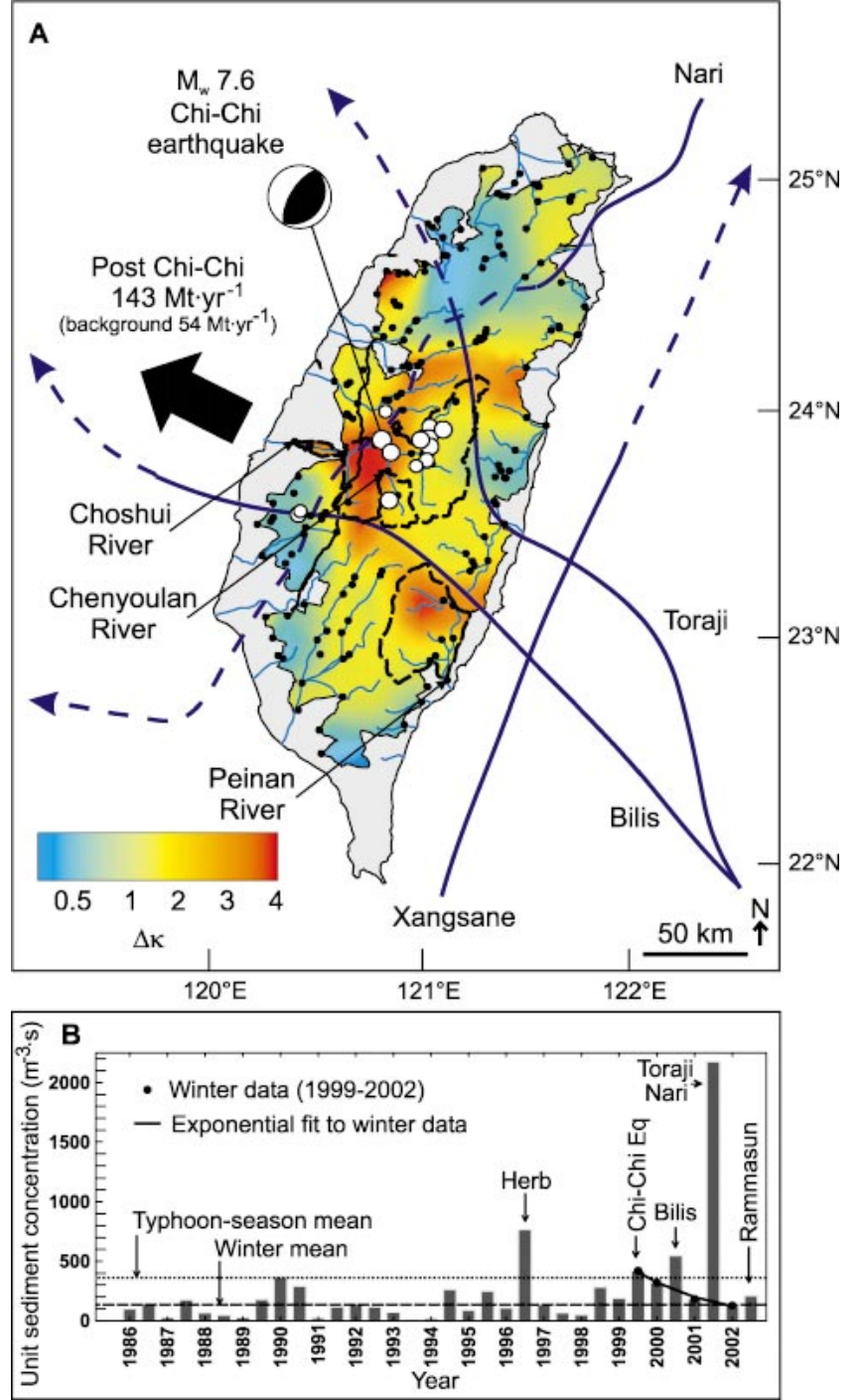

Figure 5. A: Spatial variation of change in unit sediment concentration, $\Delta_{\kappa}$, following Chi-Chi earthquake. Data from 101 catchments were smoothed using 30-km-diameter circular moving average. This length scale is median area of the catchments analyzed. Dashed lines show boundaries of named catchments. Black circles show gauging stations; open circles indicate ChiChi epicenter and aftershocks with $M_{L}>6.0$. Blue lines are tracks of subsequent typhoons: Bilis (average discharge at Choshui River mouth, $\left.Q_{\text {avg }}=4850 \mathrm{~m}^{3} \cdot \mathrm{s}^{-1}\right)$, Xangsane $\left(Q_{\text {avg }}=\right.$ $\left.1810 \mathrm{~m}^{3} \cdot \mathrm{s}^{-1}\right)$, Toraji $\left(Q_{\text {avg }}=7790 \mathrm{~m}^{3} \cdot \mathrm{s}^{-1}\right)$, and Nari $\left(Q_{\text {avg }}=2610\right.$ $\left.\mathrm{m}^{3} \cdot \mathrm{s}^{-1}\right)$. Maximum wind velocities were $105,74,74$, and 78 knots, respectively; track is solid if wind speed is > 64 knots; dashed otherwise. B: Time series of mean unit sediment concentration for 6 month periods between 1986 and 2002 in Choshui River (gray bars). Dotted line shows typhoon season mean; dashed line shows winter mean. Solid line is exponential fit to winter data (and summer 1999 when no typhoons occurred).

Greater increases in postseismic sediment concentration were observed in several mountain catchments, such as a 4.4-fold increase in the Chenyoulan watershed (Fig. 4B). The average measured suspendedsediment discharge in the Choshui River between 1986 and 1999 (a

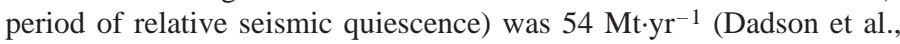
2003).

We calculated the annual suspended-sediment discharge by using a rating-curve estimate, which combines a relationship between sediment concentration and water discharge for each catchment with a record of daily water-discharge data (supplemented with hourly discharge 
measurements at one station during large storms; Water Resources Agency of Taiwan, 1970-2003). This method is likely to provide a conservative estimate of the postseismic increase in sediment discharge (Cohn, 1995). The total mass removed from the Choshui River basin during the period between the Chi-Chi earthquake and the end of 2001 was $326 \mathrm{Mt}, 175 \mathrm{Mt}$ of which was removed by Typhoon Toraji over a period of 2 days. Thus, following the earthquake, average annual suspended-sediment discharge increased by a factor of 2.6 to 143 $\mathrm{Mt} \cdot \mathrm{yr}^{-1}$. Annual averages were $14 \mathrm{Mt} \cdot \mathrm{yr}^{-1}\left(2 \mathrm{~mm} \cdot \mathrm{yr}^{-1}\right.$ across the whole catchment assuming a density of $2650 \mathrm{~kg} \cdot \mathrm{m}^{-3}$ ) in 1999 , a year with no typhoons; $81 \mathrm{Mt} \cdot \mathrm{yr}^{-1}$ in $2000\left(10 \mathrm{~mm} \cdot \mathrm{yr}^{-1}\right.$, one typhoon); and $241 \mathrm{Mt} \cdot \mathrm{yr}^{-1}$ in 2001 (30 $\mathrm{mm} \cdot \mathrm{yr}^{-1}$, three typhoons).

The time scale of the geomorphic response to the Chi-Chi earthquake is illustrated in Figure 5B, which shows the available record of averages over 6 month periods of unit sediment concentration from 1986 to 2002. The pattern of unit sediment concentration during typhoon seasons is determined by typhoon size. In contrast, the data for winter seasons (which have no typhoons) show an exponential decrease in unit suspended-sediment concentration from the elevated postearthquake value to the pre-1999 winter mean. The time for winter-season unit sediment concentration to decay to $1 / e$ of its maximum value is 2.3 yr. This observation indicates that the alluvial and colluvial stores that deliver sediment at low flow were depleted relatively rapidly following the Chi-Chi earthquake. In contrast, hillslopes continue to deliver sediment to rivers during extreme precipitation associated with typhoons. Large quantities of sediment may remain on hillslopes, causing elevated landslide and debris-flow rates in subsequent typhoons.

Elevated postseismic sediment delivery to the coast suggests that the offshore sedimentary record may contain information on locations and recurrence intervals of past earthquakes. Hyperpycnal flows are negatively buoyant fluvial discharges caused by high concentrations of suspended sediments. On the basis of the average temperature (23-28 ${ }^{\circ} \mathrm{C}$ ) and salinity (34\%o) of oceanic coastal waters around Taiwan, concentrations of 36-39 g/L will produce hyperpycnal flow (Boggs et al., 1979; Mulder and Syvitski, 1995). From hydrometric observations at the lowermost station on the Choshui River, we estimate (by using the postearthquake suspended-sediment rating curve) that $67 \%$ (up from

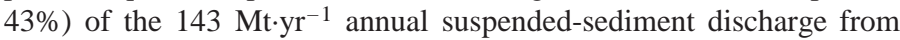
Choshui River following the Chi-Chi earthquake was delivered under conditions for which $C_{\mathrm{s}}>40 \mathrm{~g} / \mathrm{L}$. We infer that hyperpycnal plumes were formed on at least four occasions since the earthquake, each during the typhoon season. By using the background sedimentconcentration rating curve, we estimate that only one storm would have produced a hyperpycnal plume had the earthquake not occurred. Our calculations suggest that earthquake-driven geomorphic processes may leave a record of mountain-building processes in foreland stratigraphy.

\section{CONCLUSIONS}

The $1999 \mathrm{M}_{\mathrm{w}}$ 7.6 Chi-Chi earthquake has triggered at least 20,000 landslides in the Western Foothills fold-and-thrust belt of the Taiwan orogen. Coseismic landslide intensity decayed exponentially with distance from the active fault. Most of the debris from coseismic landslides has been remobilized by postseismic landslides, but most postseismic landslides have affected pristine hillslopes in a pattern that closely tracks the distribution of Chi-Chi strong ground motion. These landslides have resulted in elevated postseismic erosion rates and a cascade of sediment from hillslopes to channels. Suspended-sediment concentrations in rivers within $\sim 40 \mathrm{~km}$ of the 1999 Chi-Chi earthquake are as much as four times higher than decadal background values. The total mass removed from the epicentral catchment during the period between the Chi-Chi earthquake and the end of 2001 was $326 \mathrm{Mt}$, twothirds of which was delivered to the ocean at hyperpycnal concentrations.

\section{ACKNOWLEDGMENTS}

This work was supported by the UK Natural Environment Research Council, Faber Maunsell plc., the Taiwan National Science Council (ROC), the Royal
Society, European Union funding to the RETINA project under FP5 (EVG1CT-2001-00046), and the National Aeronautics and Space Administration (NAG5-8848). We thank D. Keefer and D. Burbank for constructive reviews.

\section{REFERENCES CITED}

Boggs, S., Wang, W.C., Lewis, F.S., and Chen, J.C., 1979, Sediment properties and water characteristics of the Taiwan shelf and slope: Acta Oceanographica Taiwanica, v. 10, p. 10-49.

Central Weather Bureau, 2003, Historical typhoon data: http://www.cwb.gov.tw/ V4/typhoon/history/typhoon-history.htm (April 2004).

Chen, W.S., Chen, Y.G., Chang, H.C., Lee, Y.H., and Lee, J.C., 2001, Palaeoseismic study of the Chelungpu fault in the Wanfung area: Western Pacific Earth Sciences, v. 1, p. 499-506.

Cohn, T.A., 1995, Recent advances in statistical methods for the estimation of sediment and nutrient transport in rivers: Reviews of Geophysics, v. 33 supplement, p. 1-18.

Dadson, S.J., Hovius, N., Chen, H., Dade, W.B., Hsieh, M.L., Willett, S.D., Hu, J.C., Horng, M.J., Chen, M.C., Stark, C.P., Lague, D., and Lin, J.C., 2003, Links between erosion, runoff variability and seismicity in the Taiwan orogen: Nature, v. 426, p. 648-651.

Eberhart-Phillips, D., and 28 others, 2003, The 2002 Denali fault earthquake, Alaska: A large magnitude slip-partitioned event: Science, v. 300 , p. $1113-1118$

Geli, L., Bard, P.Y., and Jullien, B., 1988, The effect of topography on earthquake ground motion: A review and new results: Bulletin of the Seismological Society of America, v. 78, p. 42-63.

Hartshorn, K., Hovius, N., Dade, W.B., and Slingerland, R.L., 2002, Climatedriven bedrock incision in an active mountain belt: Science, v. 297, p. 2036-2038.

Hovius, N., Stark, C.P., Chu, H.T., and Lin, J.C., 2000, Supply and removal of sediment in a landslide-dominated mountain belt: Central Range, Taiwan: Journal of Geology, v. 108, p. 73-89.

Keefer, D.K., 1994, The importance of earthquake-induced landslides to longterm slope erosion and slope-failure hazards in seismically active regions: Geomorphology, v. 10, p. 265-284.

Lee, W.H.K., Shin, T.C., Kuo, K.W., Chen, K.C., and Wu, C.F., 2001, CWB free-field strong motion data from the 921 Chi-Chi earthquake: Bulletin of the Seismological Society of America, v. 91, p. 1370-1376.

Lin, C.W., Shieh, C.L., Yuan, B.D., Shieh, Y.C., Liu, S.H., and Lee, S.Y., 2004 Impact of the Chi-Chi earthquake on the occurrence of landslides and debris flows: Example from the Chenyulan River watershed: Engineering Geology, v. 71, p. 49-61.

Lin, M.L., Wang, K.L., and Chen, T.C., 2000, Characteristics of the slope failure caused by Chi-Chi earthquake, in Loh, C.H., and Liao, W.I., eds., International workshop on annual commemoration of Chi-Chi earthquake (III): Taipei, National Center for Research on Earthquake Engineering, p. $199-209$

Lyell, C., 1830, Principles of geology, Volume 1: London, John Murray, $511 \mathrm{p}$.

Mulder, T., and Syvitski, J.P.M., 1995, Turbidity currents generated at river mouths during exceptional discharges to the world's oceans: Journal of Geology, v. 103, p. 285-299.

Pain, C.F., and Bowler, J.M., 1973, Denudation following the November 1970 earthquake at Madang, Papua New Guinea: Zeitschrift für Geomorphologie, v. 18, supplement, p. 91-104.

Pearce, A.J., and Watson, A.J., 1986, Effects of earthquake-induced landslides on sediment budget and transport over 50 years: Geology, v. 14, p. 52-55.

Shin, T.C., and Teng, T.L., 2001, An overview of the 1999 Chi-Chi, Taiwan, earthquake: Bulletin of the Seismological Society of America, v. 91, p. 895-913.

Teng, L.S., 1990, Geotectonic evolution of late Cenozoic collision in Taiwan: Tectonophysics, v. 183 , p. $57-76$

Trustrum, N.A., Gomez, B., Page, M.J., Reid, L.M., and Hicks, D.M., 1999 Sediment production, storage, and output: The role of large magnitude events in steepland catchments: Zeitschrift für Geomorphologie (Neues Folge), v. 115, supplement, p. 71-86.

Water Resources Agency of Taiwan, 1970-2003, Hydrological yearbook of Taiwan, Republic of China: Taipei, Water Resources Agency: also available at http://gweb.wra.gov.tw/wrweb (April 2004).

Wu, C.C., and Kuo, Y.H., 1999, Typhoons affecting Taiwan: Current understanding and future challenges: American Meteorological Society Bulletin, v. 80, p. $67-80$.

Yu, S.B., Chen, H.Y., and Kuo, L.C., 1997, Velocity field of GPS stations in the Taiwan area: Tectonophysics, v. 274, p. 41-59.

Yu, S.B., Kuo, L.C, Hsu, Y.J., Su, H.H., Liu, C.C., Hou, C.S., Lee, J.F., Lai, T.C., Liu, C.C., Liu, C.L., Tseng, T.F., Tsai, C.S., and Shin, T.C., 2001, Preseismic and coseismic displacements associated with the 1999 Chi-Chi, Taiwan, earthquake: Bulletin of the Seismological Society of America, v. 91 , p. $995-1012$

Manuscript received 11 March 2004

Revised manuscript received 28 April 2004

Manuscript accepted 4 May 2004

Printed in USA 